УДК: $378 ; 316.422$

DOI: https://doi.org/10.32689/2618-0065-2019-2/1-42-48

Гурковський Володимир Ігорович, доктор наук 3 державного управління, старший дослідник, перший заступник директора ВГО «Центр досліджень проблем публічного управління», 03057, м. Київ, вул. Антона Цедіка, 20, тел: 06750269 00, емейл: vladimir.gurkovskyi@gmail.com.

ORCID: 0000-0003-2021-5204

Юсеф Нахла Наймівна, доктор наук у галузі міжнародної економіки, професор, кандидат технічних наук, доцент кафедри професійної освіти та управління навчальним закладом Міжрегіональної Академії управління персоналом. Київ, Україна 03039, м. Київ, вул. Фрометівська, 2, тел: 097-794 - 99 -42, e-mail:nahla_nahla@ukr.net.

ORCID: $0000-0003-2392-0582$

\title{
ОСОБЛИВОСТІ ДЕРЖАВНОГО РЕФОРМУВАННЯ ПРОФЕСІЙНОЇ ОСВІТИ
}

Анотація. Проаналізовано концепцію впровадження сучасних стандартів професійної освіти у навчальний процес вищої школи на основі компетентнісного підходу в зарубіжних країнах. З’ясовано, що головною ідеєю компетентнісного підходу $\epsilon$ компетентнісно-орієнтована освіта, спрямована на комплексне засвоєння різних знань та способів практичної діяльності через опанування відповідними компетенція ми, завдяки яким людина успішно реалізує себе в різних галузях своєї професійної діяльності, набуває соціальної самостійності, стає мобільною та кваліфікованою. Для того, щоб професійна освіта відповідала запитам ринку праці, впроваджується компонент соціального партнерства. Його ключовим учасником є роботодавець, який формує професійні стандарти та допомагає у реалізації дуальної освіти. Крім того, в межах соціального партнерства визнаватиметься неформальна та інформальна освіта.

Підвищити якість освіти планується завдяки модернізації освітнього середовища, залучення до навчання працівників з виробництв та сфери послуг, стимулювання професійного розвитку педагогів закладу. Також створюватимуть необхідні навчальні умови для людей 3 особливими освітніми потребами.

Значної уваги потребує вирішення проблеми зниження рівня мотивації випускників шкіл щодо отримання педагогічної професії, неефективної роботи системи працевлаштування випускників вищих педагогічних навчальних закладів та недостатньої мобільності системи перепідготовки педагогічних кадрів відповідно до потреб ринку праці. Останнім часом постійно зростає рівень вимог до роботи вчителя та 
навантаження на нього, а престижність праці вчителя зменшується; досить слабкою залишається й співпраця батьків і громадськості 3 педагогічними колективами закладів освіти.

Професійна освіта в Україні здійснюється в системі вищих і середніх спеціальних навчальних закладів: в університетах, академіях, інститутах, коледжах, технікумах, технічних, педагогічних, медичних та мистецьких училищах.

На думку багатьох вчених та експертів в освітній галузі, система вищої освіти у XXI столітті буде перебувати під впливом світових трендів. Сучасна вища освіта відходить від навчання, що спрямовано на кількісний (бальний) вимір, світ цікавить, що конкретно вміє роботи випускник вищого навчального закладу, які практичні навички та компетентності отримав здобувач вищої освіти протягом всього терміну навчання.

Ключові слова: стандарти, концепція самовдосконалення, професійна діяльність, професійна стандартизація, компетентнісний підхід, європейські стандарти, навчальний план, навчальна програма. система освіти, вища педагогічна освіта, Європейська кредитна трансферна накопичувальна система (ЕКТС).

Gurkovskii Volodymyr Igorevich, Doctor of Sciences in Public Administration, Senior Researcher, First Deputy Director of the Center for Research in Public Administration Problems, 03057, Kyiv, Anton Tsedika st., 20, tel: 06750269 00, e-mail: vladimir.gurkovskyi@gmail.com.

ORCID: 0000-0003-2021-5204

Yusef Nahla Naimovha, Doctor of Science in International Economics, Professor, Candidate of Technical Sciences, Associate Professor of the Department of Professional Education and Management of Educational Institution, Interregional Academy of Personnel Management. Kyiv, Ukraine 03039, Kyiv, street. Frometovskaya, 2, tel: 097-794 - 99-42, e-mail:nahla_nahla@ukr.net.

ORCID: 0000 - $0003-2392$ - 0582

\section{FEATURES OF PUBLIC REFORMING VOCATIONAL EDUCATION}

Abstract. The concept of introduction of modern standards of vocational education in the educational process of a higher school on the basis of a competent approach in foreign countries is analyzed. It is revealed that the main idea of the competent approach is competence-oriented education, aimed at the comprehensive assimilation of various knowledge and methods of practical activity through the acquisition of appropriate competences, through which a person successfully implements himself in various fields of his professional activities, acquires social independence, becomes mobile and qualified. In order for 
vocational education to meet the needs of the labor market, a component of social partnership is being implemented. His key participant is an employer who creates professional standards and helps in the implementation of dual education. In addition, informal and informal education will be recognized within the framework of the social partnership. Improving the quality of education is planned due to the modernization of the educational environment, the involvement of employees in the production and service sectors, the promotion of professional development of teachers of the institution. They will also create the necessary training facilities for people with special educational needs.

Considerable attention needs to be given to the problem of reducing the level of motivation of school graduates to receive a pedagogical profession, ineffective work placement systems for graduates of higher pedagogical educational institutions and lack of mobility of the retraining system of teaching staff in accordance with the needs of the labor market. Recently, the level of requirements for the work of the teacher and the burden on him is constantly increasing, and the prestige of the teacher's work is decreasing; The cooperation of parents and the public with educational collectives of educational institutions remains rather weak.

Professional education in Ukraine is carried out in the system of higher and secondary specialized educational institutions: in universities, academies, institutes, colleges, technical schools, technical, pedagogical, medical and art schools.

According to many scholars and experts in the educational sector, the system of higher education in the XXI century will be influenced by world trends. Modern higher education departs from the study aimed at the quantitative (ballroom) dimension, the world is interested in what the graduates of the higher educational institution specifically know how to work, which skills and competences were acquired by a higher education student throughout the entire period of study.

Key words: standards, concept of self-improvement, professional activity, professional standardization, competence approach, European standards, curriculum, curriculum. system of education, higher education, European Credit Transfer - Accumulation System (ECTS).

Постановка проблеми. В умовах зростання ролі знань $\mathrm{i}$ технологій у житті суспільства та інтенсифікації процесів економічної й культурної глобалізації освіта все більше позиціонується як дієвий інструмент формування особистості, здатної жити в умовах динамічних змін. Одночасно масштабні суспільні зміни та модернізація освіти ставлять нові вимоги до якості підготовки та професіоналізму майбутніх фахівців. У цьому контексті особлива увага науковців приділяється з'ясуванню сутності сучасних стандартів вищої школи, впровадженню їх у навчальний процес на основі компетентнісного підходу, що в останній час набуває значного поширення у практиці зарубіжної і вітчизняної підготовки у вищій школі [1]. 
Аналіз останніх досліджень і публікацій. Проблеми впровадження сучасних стандартів у навчальний процес вищої школи на основі компетентнісного підходу в системі вищої освіти перебували в полі зору вітчизняних та зарубіжних науковців, серед яких: Н. Авшенюк, Н. Бібік, Н. Бідюк， І. Зязюн， В. Кремень， В. Луговий， О. Овчарук О. Пометун. У зарубіжній педагогіці проблеми компетентнісного підходу розглядаються у працях К. Андерк, Г. Бергман, І. Зімняя, О. Олейникова, Дж. Рамен, Р. Уайт та ін.) [2].

Мета наукової роботи - проаналізувати основні парадигматичні ідеї компетентнісного підходу у зарубіжних країнах 3 метою можливості та доцільності використання такого досвіду у вітчизняній системі вищої освіти.

Виклад основного матеріалу дослідження. На сучасному етапі розвитку освіти практично всі економічно розвинені країни здійснюють перехід або вже перейшли на реалізацію модульних стандартів, заснованих на компетенціях. Такий підхід $\epsilon$ значущим i для України, а його впровадження $є$ справою найближчого майбутнього, оскільки тільки такий підхід, як показує практика, здатний забезпечити виробництво трудовим потенціалом, необхідним для забезпечення конкурентоспроможності економіки. Важливо підкреслити, що модульний підхід, заснований на компетенціях, знаходиться в руслі концепції навчання упродовж всього життя, оскільки має на меті формування висококваліфікованих фахівців, здатних адаптуватися до мінливих ситуацій у сфері праці з одного боку, і продовжувати професійне зростання та освіту, - з іншого. Якщо порівнювати Державні галузеві стандарти вищої освіти, створені останнім часом в Україні, із стандартами, що діють у розвинених країнах, то слід відмітити принципово інші підходи до їх розробки. Наприклад, американські стандарти поширюються не тільки на етап підготовки майбутніх учителів, а й на стажування та подальший професійний розвиток, кар'єру.

Особливості такої побудови стандартів пов'язані, по-перше, з тим, що педагогічні коледжі, наприклад, при університетах США розраховані, як правило, на 4-річний термін навчання, але звання вчителя й диплом про педагогічну освіту випускники отримують лише після 2-річного стажування в школі та складання кількох екзаменів [3]. По-друге, передбачено безперервний характер освіти, оскільки вона поширюється й на професійне зростання вчителів. Для змісту професійної підготовки американських педагогів магістерського рівня характерна як наявність традиційних фундаментальних дисциплін, так i запровадження новітніх міждисциплінарних курсів. Це дає можливість запровадження спеціалізації у межах однієї магістерської спеціальності з урахуванням потреб регіону.

Такий підхід розробки стандартів, вважаємо, є цілком слушним і для української вищої школи, тому робота щодо осучаснення вітчизняних Державних стандартів має здійснюватися з урахуванням світових тенденцій. В умовах стандартизованого характеру сучасних форм, зокрема в США, 
Великій Британії, Канаді, суттєвих змін зазнали форми та методи організації навчального процесу [4]. У загальному обсязі підготовки студентів окреслилася тенденція до скорочення лекційного фонду та збільшення часу на самостійну роботу. В умовах євро інтеграційних процесів та відповідно до положень Болонської декларації про перебудову системи вищої педагогічної освіти України $є$ одним із пріоритетних завдань державної політики в галузі освіти. На сьогодні існує досить багато проблем, викликів і ризиків, серед яких:

Відсутність на довгострокову перспективу єдиного концептуального підходу що до функціонування та розвитку національної системи освіти;

Низький рівень матеріально - технічного, навчально - методичного та інформаційного забезпечення навчальних закладів;

Слабка мотивація суспільства та бізнесу до інвестування в освіту; недостатня відповідність між вимогами суспільства до функціонування системи вищої освіти та ії фінансовим забезпеченням з боку держави;

Відсутність дієвої системи соціально - економічних стимулів для роботи педагогічних і науково - педагогічних працівників, що відповідають запитам ринку праці.

Модернізоване освітнє середовище, багатоканальне фінансування та управління на місцях - такими $є$ основні цілі реформування професійнотехнічної освіти в Україні.

Професійно - технічна освіта надається в середніх професійно технічних училищах, які забезпечують підготовку кваліфікованих робітників.

Сучасних роботодавців на ринку праці хвилюють технічні навички працівників, $з$ цією метою проводяться тренінг-курси, семінари. Безперервна освіта акумулює досвід гуманітарної, загальної та професійної освіти, підносить значення самоосвіти, робить наголос на поступальності вертикального та горизонтального освітнього процесу розвитку творчого потенціалу особистості та на необхідності інтеграції формальної, неформальної та інформальної складових освітнього процесу.

Це підтверджується обсягом державної підтримки науки, приватними інвестиціями та кількістю представлених патентів на винахід в рік. Так, наприклад, щорічно Японія має близько 150 тис. патентів, тоді як США - 75 тисяч, Франція обіймає третю сходинку - 30 тисяч патентів. I саме ці країни $€$ найпоказовішими представниками освітнього простору своїх континентів. Наука у стінах вищої школи має провокувати нові знання, виступати фундаментом інновацій та задавати майбутні орієнтири розвитку цієї галузі. У зв’язку зі зростанням популярності наукових досліджень змінюється підхід до освітнього процесу, студент отримує новий статус - активного дослідника, що самостійно застосовує під час навчальної та наукодослідницької роботи навички пошукової, конструкторської та винахідницької діяльності. 
Висновки і перспективи подальших досліджень. Як ми бачимо, в різних країнах аналіз ринку праці та формування професійних стандартів здійснюється за різними методиками. Хоча фактично в основу кожної покладено метод функціонального аналізу. Узагальнення методів й механізмів аналізу потреб ринку праці в країнах ЄС дало можливість встановити, що, незважаючи на різні підходи до виявлення проблем i тенденцій розвитку ринку праці та залучення різних державних і приватних структур до досліджень, зусилля європейських країн спрямовані на постійний моніторинг ринку праці, своєчасне виявлення актуальних проблем, прогнозування й аналіз затребуваних професій, кваліфікацій та компетенції на державному, регіональному, галузевому рівнях та адекватне відображення результатів досліджень у програмах навчальних закладів [5].

У ракурсі здійсненого дослідження вважаємо за доцільне детальніше вивчати зарубіжні підходи до виявлення проблем і тенденцій розвитку ринку праці і залучення державних i приватних структур до досліджень задля їх адаптації до освітнього простору України. Вивчення літератури дає підстави стверджувати, що системи професійної підготовки педагогічних кадрів у системі вищої освіти України має на меті виконання таких завдань: здійснити реформи, спрямовані на модернізацію системи вищої педагогічної освіти та організації навчання у ВНЗ.

Підвищити якість освіти планується завдяки модернізації освітнього середовища, залучення до навчання працівників з виробництв та сфери послуг, стимулювання професійного розвитку педагогів закладу.

На особливу увагу заслуговує розв'язання питання подолання невідповідності системи контролю якості освіти міжнародним стандартам та вдосконалення системи оцінювання якості підготовки випускників вищих навчальних закладів, зокрема й педагогічних.

Подолання існуючих розбіжностей у функціонуванні національної та європейської систем підвищення ефективності професійного становлення вчителів в Україні.

\section{Jimepamypa:}

1. Дубасенюк О. Розвиток вищої освіти: тенденції та перспективи / О. Дубасенюк // Людиноцентризм як основа гуманітарної політики України: освіта, політика, економіка, культура : матер. Всеукр. конф. - К., 2011. - С. 135-142.

2. Гордієнко Т. В. Із зарубіжного досвіду формування педагогічної майстерності / Т. В. Гордієнко // Наукові записки НДУ ім. М. Гоголя. Сер. : Психолого-педагогічні науки : зб. наук. пр. / Ніжин. держ. ун-т ім. М. Гоголя. - Ніжин : Вид-во НДУ ім. М. Гоголя, - 2012. - № 2. - С. 161-16.

3. Удод О. А. Інновації в освіті - основа модернізації галузі в сучасних умовах [Електронний ресурс] / О. А. Удод // Інноватика в сучасній освіті. Сьомий міжнародний форум 20-22 жовтня 2015 p. - Режим доступу : http:// innovosvita.com.ua/index.php/ru/results/catalogue/24. 
4. Авшенюк Н. М. Стандартизація професійної підготовки вчителів у Англії й Уельсі (кінець XX - початок XXI ст.) : автореф. дис. ... канд. пед. наук : спец. 13.00.04 «Теорія та методика професійної освіти» / Н. М. Авшенюк. - К., 2005. - 21 с. 2.

5. Закон України «Про вищу освіту» [Електронний ресурс] / Закон від 1 липня 2014 р. № 1556-VII. - Режим доступу : http://zakon4.rada.gov.ua/laws/show/1556-18/page.

\section{References:}

1. Dubaseniuk, O. (2011). Rozvytok vyshchoi osvity: tendentsii ta perspektyvy [Higher Education Development: Trends and Prospects]. Liudynotsentryzm yak osnova humanitarnoi polityky Ukrainy: osvita, polityka, ekonomika, kultura - Human Centerism as the Basis of Humanitarian Policy in Ukraine: Education, Politics, Economics, Culturep: Proceedings of the All-Ukrainian Conference. (pp. 135-142). Kyiv [in Ukrainian].

2. Hordiienko, T. V. (2012). Iz zarubizhnoho dosvidu formuvannia pedahohichnoi maisternosti [From foreign experience in the formation of pedagogical skill]. Naukovi zapysky NDU im. M. Hoholia. Ser. : Psykholoho-pedahohichni nauky - Scientific notes of Nizhyn Gogol State University. Series: Psychological and pedagogical sciences, 2, 161-16 [in Ukrainian].

3. Udod, O. A. (n.d.). Innovatsii v osviti - osnova modernizatsii haluzi v suchasnykh umovakh [Innovation in education - the basis of modernization of industry in modern conditions]. Innovatyka $v$ suchasnii osviti. Somyi mizhnarodnyi forum - Innovation in modern education: Seventh International Forum. Retrieved from http://movaliteratura.at.ua/zdvr/innovacii.doc [in Ukrainian].

4. Avsheniuk, N. M. (2005). Standartyzatsiia profesiinoi pidhotovky vchyteliv u Anhlii y Uelsi (kinets XX - pochatok XXI st.) [Standardization of teacher training in England and Wales (end of XX - the beginning of XXI centuries)]. Extended abstract of candidate's thesis. Kyiv [in Ukrainian].

5. Zakon Ukrainy «Pro vyshchu osvitu» : vid 1 lypnia 2014 r., № 1556-VII [Law of Ukraine "On Higher Education" from July 1 2014, № 1556-VII]. (n.d.). zakon.rada.gov.ua. Retrieved from http://zakon4.rada.gov.ua/laws/show/1556-18/page [in Ukrainian]. 